\title{
Väinö Kannisto: Career and Scholarly Work
}

\author{
TAPANI VALKONEN, Ph.D., Professor in Demography \\ Population Research Unit, Department of Sociology, \\ University of Helsinki, Finland
}

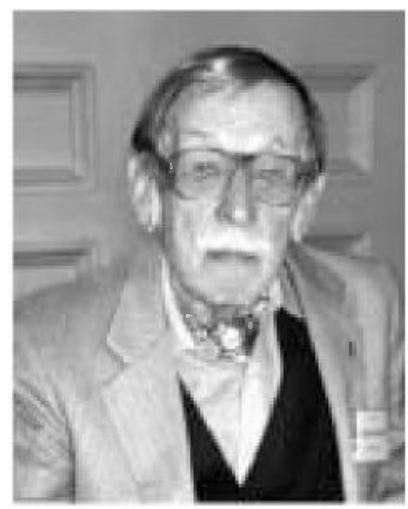

Dr. Väinö Kannisto, the grand old man of Finnish demography, died unexpectedly on February 16th, 2002 in Lisbon at the age of 85 . He was born in Helsinki on September 24th, 1916.

Väinö Kannisto's father, Artturi Kannisto, was a professor of Fenno-ugric philology. Väinö was not attracted to the humanities, but chose economics and statistics instead. He received his M.A. degree from the University of Helsinki in 1938 and started his work career as an assistant actuary at the Division of Population Statistics of the Central Statistical Office of Finland in 1939. This appointment lasted until 1945, but during most of this period Kannisto served in the army during both of the wars which Finland fought against the Soviet Union, the Winter War in 1939 - 40 and the Continuation War, in 1941 - 44. He held the military rank of lieutenant at the end of the war.

During the Continuation War Kannisto served as an officer in the troops occupying Eastern Karelia, the Soviet territory east of the Finnish border. In 1942 he organized the collection of data for a study he planned would become his $\mathrm{Ph}$.D. thesis. Teachers and ambulatory nurses interviewed ethnic Finnish women living in the area. The interviews covered the marital histories of the women and the dates of births and possible deaths of all the children ever born to them. The total number of interviews was more than 5,500.

Kannisto did not use the Karelian data for his doctoral dissertation. The data collected from the Russian territory temporarily occupied by Finland were politically sensitive. According to Kannisto there was also another reason not to use the data: his professor considered the data too unreliable because they were not based on official documents.

Kannisto donated the data to the Department of Sociology at the University of Helsinki in the 1980s. Through an initiative taken by Dr. Veijo Notkola the material was 
computerized. Riikka Shemeikka and students attending her research seminar analyzed the data and prepared a mimeographed report in 1996 (Raitis \& Ahola, 1996).

Soon after the war, in 1947, Kannisto earned his Ph.D. degree from the University of Helsinki. The title of the thesis was The Causes of Death as Demographical Factors in Finland (in Finnish with a summary in English). The quality of the Finnish mortality statistics had improved essentially in 1936, when the entire system of data collection was remodeled and a new cause of death classification was adopted. Kannisto estimated the contribution of different causes of death to the mortality of men and women and analyzed regional differences in mortality by cause of death. The regional analysis revealed that mortality from heart diseases was higher in Eastern than Western Finland. These findings led to an extensive "East-West study" on the causes of heart diseases in the 1950s (Karvonen \& al. 1970). This study was important for the development of the Finnish epidemiological research tradition and later gave impetus to the world-famous North Karelia project for the prevention of heart diseases.

Kannisto pursued post-doctoral studies in bio-statistics at the Johns Hopkins School of Hygiene and Public Health in Baltimore in 1947 - 48 and in advanced economic statistics at the University of Pennsylvania in Philadelphia in 1948 - 49. He worked as a statistical expert for the World Health Organization from 1949 to 1955. In 1956 he returned to Finland, albeit for one year only, acting as the director of the general division of the Central Statistical Office. During the long period from 1957 to 1982 Kannisto worked as a United Nations expert and interregional advisor in demographic and social statistics. He carried out more than 200 missions in almost 100 countries. In 1982 - 90, after his retirement, he undertook about 30 planning, advisory and evaluation missions on behalf of several United Nations organizations. After these missions had been concluded Dr. and Mrs. Kannisto moved to Lisbon, where Mrs. Kannisto had spent her childhood.

In the 1980s Kannisto resumed his demographic research work on mortality, which had been suspended since the 1940s. He worked on his research projects almost full time up to his death. Since 1989 he had been affiliated with the project on maximal length of life in the Cambridge Group for the History of Population and, since 1992, he had been a Distinguished Research Fellow at the Odense University Medical School in Denmark.

Kannisto started his new career in mortality research with an article titled Focus on Adult Mortality published in the Yearbook of Population Research in Finland in 1986 and with two reports on geographic differences in infant mortality in the same year (see the list of publications below). These publications were followed by several articles in major international demographic journals and two path-breaking books (Development of Oldest-Old Mortality, 1950 - 1990: Evidence from 28 Developed Countries and The Advancing Frontier of Survival, published in 1994 and 1996, 
respectively). Kannisto co-authored the book The Force of Mortality at Ages 80 to 120 with Roger Thatcher as well as two books published by Statistics Finland (Revised Life Tables for Finland 1881 - 1990 with Mauri Nieminen and Abridged Life Tables for Finland 1751 - 1880 with Oiva Turpeinen). Kannisto's last piece of published work was Years Added to Life in Old Age, an article in the Yearbook of Population Research in Finland 2002.

Most of Kannisto's research was based on the Oldest-Old Database created by him with the assistance of Roger Thatcher. The Kannisto-Thatcher Database compiled deaths and population counts at ages above 80 for about 30 countries for which reliable data were available. A difficult problem in studying mortality among the oldestold is that the size of the population at very high ages is not well known. Kannisto was able to solve this problem by applying the method of extinct generations presented originally by Paul Vincent in 1951. When this method is applied, the populations at risk in the oldest age groups are obtained by summing up the deaths in each cohort beginning with the oldest.

The Kannisto-Thatcher Database is the first data set that makes it possible to obtain reliable results on trends and international differences in mortality among very old people, including centenarians. Kannisto's studies showed a clear decline in the oldest-old mortality in all countries, but revealed important differences in the timing and pace of the decline. Kannisto demonstrated that the decline in old-age mortality had been caused by period factors with simultaneous and apparently immediate effects on all old-age groups. The decline was thus not the result of supposedly healthier cohorts growing older.

The Kannisto-Thatcher Oldest-Old Database was initiated at the Odense University Medical School in Denmark. It is now maintained and updated by the Max Planck Institute for Demographic Research in Rostock as the "crown jewel of the Institute's data holdings" as stated by the director of the Institute, Dr. Jim Vaupel (2002).

Väinö Kannisto had reached the age of 70 in 1986, when the first articles of his "new" research career were published. In 15 years, out of passion for demographic research, he produced an amazing number of important contributions to the understanding of trends and differentials in mortality. These contributions were recognized not only by experts in the field. The French Foundation IPSEN awarded him the esteemed Prix de Longevite for his research merits in 1997. Kannisto donated the award to the Family Federation of Finland for the establishment of the Väinö Kannisto Foundation, which annually awards a prize for the best Finnish demographic thesis in the field of mortality and health research. 
Kannisto often visited Finland and was in active contact with Finnish researchers. The Finnish Statistical Society invited him to be an honorary member in 1990 and the Finnish Demographic Association in 1997. The University of Tampere conferred him the title of Honorary Doctor in 1985.

The information on Väinö Kannisto's career presented here is mainly based on his curriculum vitae. I am grateful to Kari Pitkänen for his assistance in the preparation of this paper.

\section{References}

Karvonen, M. J., E. Orma, S. Punsar, V. Kallio, M. Arstila, K. Luomanmäki, and J. Takkunen. 1970. Coronary heart disease in seven countries 6. Five year experience in Finland. Circulation 41, Suppl. 1:1:52-62.

Raitis, R., and J. Ahola. (editors). 1996. Hedelmällisyys ja kuolleisuus Itä-Karjalassa 1800luvun lopulta toiseen maailmansotaan. [Fertility and Mortality in Eastern Karelia from the 19th century until the Second World War]. Tutkimusharjoituskurssin loppuraportti. Helsingin yliopisto: sosiologian laitos.

Vaupel, J. W. 2002. Dr. Väinö Kannisto: A Reflexion. Demographic Research 6, article 5.

Vincent, P. 1951. La mortalité des vieillards. Population 6:181-204.

\section{List of Väinö Kannisto's major demographic publications on mortality}

Kannisto, V. 1945. Mikä lyhentää elinaikaamme? [What shortens our lives?, in Finnish, with German summary]. Kansantaloudellinen aikakauskirja 41:377-383.

Kannisto, V. 1947. Kuolemansyyt väestöllisinä tekijöinä Suomessa. [The Causes of Death as Demographical Factors in Finland, in Finnish, with English summary]. Kansantaloudellisia tutkimuksia XV. Helsinki: Kansantaloudellinen yhdistys.

Kannisto, V. 1951. Miksi Suomen miehet kuolevat ennenaikaisesti? [Causes of untimely death among Finnish men]. Duodecim 67:1108-1112.

Kannisto, V. 1986. Factores associados as diferenças geograficas da mortalidade infantile em Portugal desde 1950. Revista do Centro de Estudos Demográficos, No. 28.

Kannisto, V. 1986. Focus on Adult Mortality. Yearbook of Population Research in Finland XXIV:5-13. Helsinki: The Population Research Institute, The Family federation of Finland.

Kannisto, V. 1986. Geographic differentials in infant mortality in Finland in 1871-1983. Research Reports 126. Helsinki: Statistics Finland.

Kannisto, V. 1988. Imeväiskuolleisuuden alueellisista eroista. [On regional differences in infant mortality]. Sosiaalilääketieteellinen Aikakauslehti 25:108-117.

Kannisto, V. 1988. Mortality at Old Age in the Nordic Countries. Yearbook of Population Research in Finland XXVI:5-21. Helsinki: The Population Research Institute, The Family Federation of Finland.

Kannisto, V. 1988. On the Survival of Centenarians and the Span of Life. Population Studies 42:389-406. 
Kannisto, V. 1990. Mortality of the elderly in late $19^{\text {th }}$ and early $20^{\text {th }}$ century Finland. Research Reports 175. Helsinki: Statistics Finland.

Kannisto, V. 1990. Vanhusten alueelliset kuolleisuuserot Suomessa 1850-luvulta alkaen. [Geographical differences in the mortality of the elderly in Finland since the 1850s]. Sosiaalilääketieteellinen Aikakauslehti 27:417-426.

Kannisto, V. 1991. Frailty and Survival. Genus 47:101-118.

Kannisto, V. 1994. Development of Oldest-OldMortality, Evidence from 28 Developed Countries, 1950-1990. Monographs on Population Aging, No 1. Odense: Odense University Press.

Kannisto, V., J. Lauritsen, A. R. Thatcher, and J. W. Vaupel. 1994. Reductions in Mortality at Advanced Ages: Several Decades of Evidence from 27 Countries. Population and Development Review 20:793-810, 921-924.

Kannisto, V. 1996. The Advancing Frontier of Survival. Monographs on Population Aging, № 3. Odense: Odense University Press.

Kannisto, V., and M. Nieminen. 1996. Revised Life Tables for Finland 1881-1990. Population 1996:2. Helsinki: Statistics Finland.

Kannisto, V., K. Christensen, and J. W. Vaupel. 1997. No Increased Mortality in Later Life for Cohorts born during Famine. American Journal of Epidemiology 145: 987-994.

Turpeinen, O., and V. Kannisto. 1997. Abridged Life Tables for Finland 1751-1880. Population 1997:5. Helsinki: Statistics Finland.

Thatcher, A. R., V. Kannisto, and J. W. Vaupel. 1998. The Force of Mortality at Ages 80 to 120. Monographs on Population Aging, No 5. Odense: Odense University Press.

Vaupel, J. W., J.R. Carey, K. Christensen, T. E. Johnson, A. I. Yashin, N. V. Holm, I. A. Iachine, V. Kannisto, A. A. Khazaeli, and P. Liedo. 1998. Biodemographic Trajectories of Longevity. Science 280:855-860.

Kannisto, V. 1998-1999. Longevity in the Light of the Latest Data. Yearbook of Population Research in Finland XXXV:24-29. Helsinki: The Population Research Institute, The Family Federation of Finland.

Kannisto, V., M. Nieminen, and O.Turpeinen. 1999. Finnish Life Tables since 1751. Demographic Research 1, article 1.

Kannisto, V. 2000. Measuring the Compression of Mortality. Demographic Research 3, article 6.

Thatcher, R., V. Kannisto, and K. Andreev. 2002. The Survivor Ratio Method for Estimating Numbers at High Ages. Demographic Research 6, article 1.

Kannisto, V. 2002. Years Added to Life in Old Age. Yearbook of Population Research in Finland XXXVIII:97-106. Helsinki: The Population Research Institute, The Family Federation of Finland. 